\title{
Caspases rather than calpains mediate remodelling of the fodrin skeleton during human placental trophoblast fusion
}

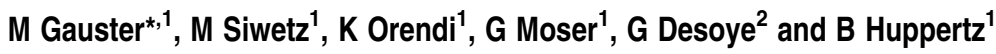

Fusion of cytotrophoblasts with the overlying syncytiotrophoblast is an integral step in differentiation of the human placental villous trophoblast. Multiple factors, such as growth factors, hormones, cytokines, protein kinases, transcription factors and structural membrane proteins, were described to modulate trophoblast fusion. However, the knowledge on remodelling of the membrane-associated cytoskeleton during trophoblast fusion is very limited. This study describes the link between remodelling of spectrin-like $\alpha$-fodrin and intercellular trophoblast fusion. Experiments with primary trophoblasts isolated from term placentas and the choriocarcinoma cell line BeWo revealed a biphasic strategy of the cells to achieve reorganization of $\alpha$-fodrin. Syncytialization of trophoblasts was accompanied by down-regulation of $\alpha$-fodrin mRNA, whereas the full-length $\alpha$-fodrin protein was cleaved into 120 and $150 \mathrm{kDa}$ fragments. Application of calpeptin and calpain inhibitor III did not affect $\alpha$-fodrin fragmentation in primary term trophoblasts and forskolin-treated BeWo cells, but decreased secretion of $\beta$ human chorionic gonadotropin. In contrast, inhibitors of caspases 3,8 and 9 attenuated generation of the $120 \mathrm{kDa}$ fragment and a general caspase inhibitor completely blocked fragmentation, suggesting an exclusive function of caspases in $\alpha$-fodrin remodelling. Immunofluorescence double staining of human placenta revealed co-localization of active caspase 8 with $\alpha$-fodrin positive vesicles in fusing villous cytotrophoblasts. These results suggest that caspase-dependent fragmentation of $\alpha$-fodrin may be important for reorganization of the sub-membranous cytoskeleton during trophoblast fusion.

Cell Death and Differentiation (2010) 17, 336-345; doi:10.1038/cdd.2009.133; published online 2 October 2009

Human placental villi are covered by the syncytiotrophoblast, a multinucleated layer devoid of lateral cell borders. This syncytial layer is in direct contact with maternal blood and constitutes the foeto-maternal blood barrier. Nuclei within the syncytiotrophoblast do not replicate ${ }^{1}$ and thus make the syncytium dependent on chromosomal DNA supplied from an exogenous source to counterbalance the continuous release of apoptotic nuclei into the maternal circulation. Acquisition of fresh nuclei is provided by the underlying cell layer of mononucleated cytotrophoblasts. Some of these villous cytotrophoblasts start to differentiate and consequently fuse with the overlying syncytiotrophoblast. This way not only nuclei, but also organelles and cytoplasm are transferred into the syncytium. Differentiation of villous cytotrophoblasts can be induced by growth factors, cytokines and hormones, which activate transcription of fusogenic genes, encoding proteins involved in trophoblast fusion. ${ }^{2}$

Fusion and conversion from the mononucleated to the syncytial state is fundamental for successful pregnancy, as the syncytiotrophoblast fulfils not only exchange of gas and nutrients between foetus and mother, but also performs endocrine functions. To meet these demands, the syncytiotrophoblast gains features originally missing in the villous cytotrophoblast compartment such as production of hormones like human chorionic gonadotropin (hCG), human placental lactogen ${ }^{3}$ or leptin, ${ }^{4}$ which are important for maintenance of pregnancy and adaptation of the maternal metabolism. However, not only hormones, also enzymes such as p450 aromatase ${ }^{5,6}$ are solely expressed by the syncytiotrophoblast.

In addition to metabolic and endocrine adaptation, differentiation may also affect composition and arrangement of the cytoskeleton. At this point, the difference between a syncytium and a synkaryon should be noted, as the former arises from fusion of separate cells and the latter is formed by repeated karyokinesis without cytokinesis. Bearing this in mind, intercellular fusion comprises not only merger of cytoplasmic membranes and redistribution of cytoplasmic organelles, it also requires reorganization of the complete cytoskeleton.

The complex process of intercellular fusion includes at least three major stages. Initial steps such as (1) remodelling of the membrane architecture ${ }^{7}$ and (2) synthesis of proteins involved in membrane interaction ${ }^{8-10}$ are preceding the central step of (3) fusion pore formation. Finally, post-fusion steps such as fusion pore expansion ${ }^{11}$ and cytoplasmic reorganization take place.

\footnotetext{
${ }^{1}$ Institute of Cell Biology, Histology and Embryology, Center for Molecular Medicine, Medical University of Graz, Graz, Austria and ${ }^{2}$ Department of Obstetrics and Gynecology, Medical University Graz, Graz, Austria

${ }^{*}$ Corresponding author: M Gauster, Institute of Cell Biology, Histology and Embryology, Medical University of Graz, Harrachgasse 21/VII, Graz 8010, Austria.

Tel: + 43316380 7611; Fax: + 43316380 9625; E-mail: martin.gauster@medunigraz.at

Keywords: human placenta; trophoblast differentiation; trophoblast fusion

Abbreviations: CAMP, cyclic adenosine monophosphate; $\beta \mathrm{hCG}$, human chorionic gonadotropin beta subunit; DMSO, dimethyl sulfoxide; hPL, human placental lactogen; HUVEC, human umbilical vein endothelial cells; TGF- $\beta$, transforming growth factor-beta

Received 22.1.09; revised 17.7.09; accepted 30.7.09; Edited by R De Maria; published online 02.10.09
} 
This study focuses on the remodelling of spectrin-like $\alpha$-fodrin ( $\alpha$ ll-spectrin, non-erythroid spectrin) during intercellular fusion of trophoblasts. Spectrins are composed of $\alpha$ and $\beta$ heterodimers, which constitute the major component of the sub-membranous cytoskeleton of all cells. The spectrin network has a triangular structure, important for maintenance of cellular shape and membrane stability. Proteolytic cleavage of $\alpha$-fodrin is implicated with apoptotic processes, as it is believed to be associated with membrane blebbing in apoptotic cells. ${ }^{12}$ Fragmentation of $\alpha$-fodrin, an early event in apoptosis, is alternatively performed by calpain and caspase 3, which leads to generation of 150, 145 and $120 \mathrm{kDa}$ cleavage products. ${ }^{13}$ However, $\alpha$-fodrin cleavage may also proceed independent of calpain and caspase 3 activity, as shown during TGF- $\beta$-induced apoptosis of a murine $B$-cell line. ${ }^{14}$ In addition, fragmentation of $\alpha$-fodrin occurs during differentiation of nerve cells ${ }^{15}$ and lens fibres ${ }^{16,17}$ as well as during myoblast fusion. ${ }^{18}$ Here, we show localization of $\alpha$-fodrin in human placental tissues and address the issue of spectrin remodelling during intercellular trophoblast fusion.

\section{Results}

Rearrangement of the $\alpha$-fodrin network in human placenta and trophoblast cells. Immunofluorescence of human placental sections showed distinct staining of $\alpha$-fodrin in mononucleated cytotrophoblasts, stromal cells and endothelial cells of stromal blood vessels. In first trimester (Figure 1a) and term placenta (not shown), $\alpha$-fodrin was associated with apical and lateral cell borders of cytotrophoblasts, but was absent in the overlying syncytiotrophoblast.

A similar rearrangement of the $\alpha$-fodrin network was observed in trophoblast cells when differentiation from the mononucleated to the syncytial state occurred. The trophoblast derived cell line BeWo showed pronounced $\alpha$-fodrin staining as long as cells remained in an unstimulated, mononucleated state (Figure 1b). Forskolin triggers fusion of BeWo cells by increasing intracellular cAMP concentration through adenylyl cyclase activation. ${ }^{19}$ If BeWo cells were treated with forskolin cell borders and the associated $\alpha$-fodrin network vanished in fusing cells (Figure 1c, asterisks), whereas the network remained intact in mononucleated cells (Figure 1c, arrowheads). This effect was also observed in isolated primary term trophoblasts, which spontaneously formed syncytia after 2 days of cultivation in vitro. Although $\alpha$-fodrin lining was maintained in mononucleated cells (Figure 1d, arrowheads), it disappeared in syncytial areas (Figure 1d, asterisks). Forskolin treatment provoked a fusion rate of $36.0 \%( \pm 1.3 \%)$ in BeWo cells, whereas primary term trophoblasts showed a fusion rate of $18.2 \%( \pm 3.9 \%)$ after $48 \mathrm{~h}$ cultivation.

Down-regulation of $\alpha$-fodrin mRNA in trophoblast cells during syncytialization. Down-regulation of $\alpha$-fodrin mRNA expression was pronounced in BeWo cells treated with forskolin. Stimulation with the fusion inducing reagent led to an expression level of only $37 \%$ compared with vehicle-treated cells after $48 \mathrm{~h}$ (Figure 2a). In primary term trophoblasts, $\alpha$-fodrin mRNA expression was also downregulated in a time-dependent way and declined after $72 \mathrm{~h}$ of culture to $52 \%$ of the expression level at cultivation start (Figure 2b). This effect was also observed in microarray analysis, which revealed a down-regulation of both $\alpha$-fodrin (2.19-fold) and $\beta$-fodrin (2.21-fold) in forskolin-treated BeWo cells after cultivation for $72 \mathrm{~h}$.

Oxygen regulates $\alpha$-fodrin mRNA in BeWo cells. Earlier studies revealed an integral function of oxygen tension in modulating trophoblast syncytialization, as cultivation under low oxygen impaired intercellular fusion of primary trophoblasts and BeWo cells. ${ }^{20-22}$ To address whether oxygen tension also affects $\alpha$-fodrin expression, BeWo cells were cultured under a broad range of oxygen concentrations, including $2 \%$ (placental normoxia in first trimester), $8 \%$ (placental normoxia at term), 16\% (placental hyperoxia was concluded in pregnancy disorders ${ }^{23}$ ) and $20 \%$ (normal cell culture value) oxygen. Cultivation of unstimulated BeWo cells under these conditions for $48 \mathrm{~h}$ indeed affected the expression level of $\alpha$-fodrin, as rising oxygen concentrations impaired mRNA expression of $\alpha$-fodrin: when oxygen was set to $16 \%, \alpha$-fodrin expression decreased to $76.5 \%( \pm 2.4 \%$, $P<0.005$ ) of the expression level at $2 \%$ oxygen (Figure $2 \mathrm{c}$ ). Similar was the effect at $20 \%$ oxygen and here $\alpha$-fodrin expression declined to $78.8 \%( \pm 5.7 \%, P<0.05)$ compared with the expression at $2 \%$ oxygen (Figure $2 \mathrm{c}$ ). In contrast, expression of hCG beta subunit mRNA (Figure 2d) as well as secreted $\beta$ hCG protein (not shown) corresponded with oxygen concentrations, as it was up-regulated with rising oxygen concentrations. Thus, low oxygen levels may well be responsible for impaired trophoblast fusion as expression of $\beta \mathrm{hCG}$ mRNA was 2.4- and 3.7-fold higher at 8 and $20 \%$ oxygen, respectively, compared with expression at $2 \%$ oxygen (Figure $2 \mathrm{~d}$ ).

Fragmentation of $\alpha$-fodrin protein during trophoblast fusion. Forskolin stimulation of BeWo cells for $48 \mathrm{~h}$ led to augmented $\alpha$-fodrin fragmentation as observed by generation of truncation products of approximately 150 and $120 \mathrm{kDa}$ (Figure 3a). In BeWo cells, fragmentation of $\alpha$-fodrin proceeded in a time- and forskolin-dependent manner, whereas simultaneous incubation with DMSO alone caused only weak fragmentation. Interestingly, forskolin treatment provoked only low $\alpha$-fodrin cleavage in Jeg- 3 cells and had no effect in JAR cells, both choriocarcinoma cell lines that do not show syncytial fusion (not shown). In BeWo cells, forskolin-induced $\alpha$-fodrin fragmentation and syncytialization was associated with a time-dependent increase in $\beta \mathrm{hCG}$ secretion (Figure $3 b$ ). In primary term trophoblasts, $\alpha$-fodrin was also fragmented during culture, albeit fragmentation proceeded slower (Figure 3c). Immunoblots of primary term trophoblasts and forskolin-challenged BeWo cell lysates revealed that $\alpha$-fodrin was cleaved into 150 and $120 \mathrm{kDa}$ fragments. However, it has been shown that $\alpha$-fodrin is cleaved into 150, 145 and $120 \mathrm{kDa}$ break down products in apoptotic cells. $^{24}$ Thus, the question arose whether the $145 \mathrm{kDa}$ fragment was not detected because of insufficient protein separation by electrophoresis or whether it was even 

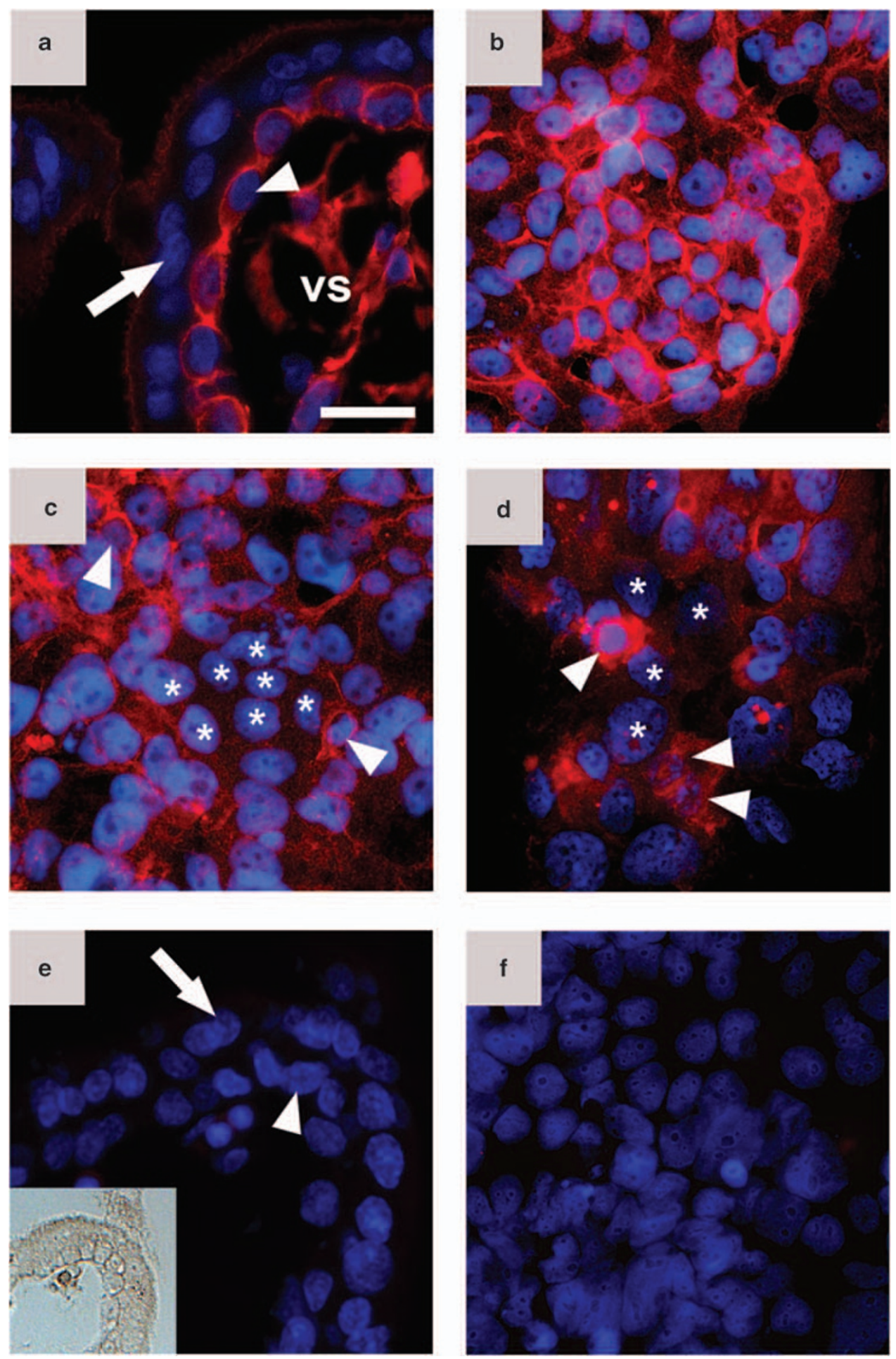

Figure 1 Immunofluorescence staining of $\alpha$-fodrin in human first trimester placenta, BeWo cells and primary term trophoblasts. (a) In human first trimester placenta, $\alpha$-fodrin was detected in cytotrophoblasts (arrowhead), stromal cells and vascular endothelial cells in the villous stroma (versus). In contrast to villous cytotrophoblasts, $\alpha$-fodrin was virtually absent in the syncytiotrophoblast (arrow). (b) BeWo cells treated with vehicle only (DMSO, $0.2 \%$ ) for $48 \mathrm{~h}$ remained in a mononucleated state, (c) whereas forskolin $(20 \mu \mathrm{M}, 48 \mathrm{~h})$-stimulated BeWo cells to form multinucleated syncytia devoid of $\alpha$-fodrin (asterisks). Some BeWo cells remained mononucleated (arrowheads). (d) Cultivation of primary term trophoblasts for $48 \mathrm{~h}$ showed spontaneously fused trophoblasts (asterisks) and mononucleated trophoblasts (arrowheads). Incubation with negative control mouse lgG1 gave no staining on (e) syncytiotrophoblast (arrow) and cytotrophoblasts (arrowhead) of human first trimester placenta. (e, insert) For better morphological orientation, a bright field image from the same section shown in (e) was taken. (f) Incubation with negative control mouse lgG1 also gave no staining on BeWo cells. Scale bar represents $20 \mu \mathrm{m}$ 
not generated in fusing trophoblasts. To solve this problem, the $\alpha$-fodrin fragmentation pattern of forskolin-treated BeWo cells was compared with that of human umbilical vein endothelial cells (HUVEC), treated with calcium ionophores
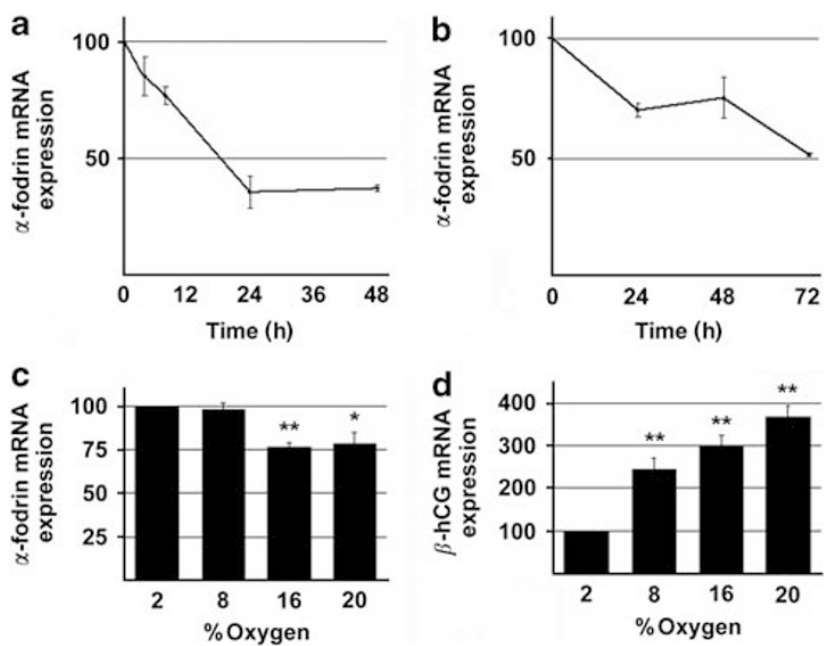

Figure 2 Real-time RT-PCR analyses of $\alpha$-fodrin and $\beta$ hCG mRNA expression in BeWo cells and primary term trophoblasts. (a) Expression of $\alpha$-fodrin mRNA was down-regulated to $37 \%$ in forskolin $(20 \mu \mathrm{M})$-treated BeWo cells compared with vehicle control (DMSO, $0.2 \%$ ) after $48 \mathrm{~h}$. (b) In primary term trophoblasts $\alpha$-fodrin, mRNA expression decreased to $52 \%$ after $72 \mathrm{~h}$ culture, compared with starting conditions. (c) In BeWo cells, expression level of $\alpha$-fodrin was dependent on oxygen. Cultivation of BeWo cells for $48 \mathrm{~h}$ at 16 and $20 \%$ oxygen decreased $\alpha$-fodrin expression to 76.5 and $78.8 \%$, respectively, compared with expression at $2 \%$ oxygen. (d) In contrast, expression of $\beta \mathrm{hCG}$ mRNA increased with rising oxygen concentrations. $\beta \mathrm{hCG}$ mRNA expression was 3.7-fold higher in BeWo cells cultivated at $20 \%$ oxygen compared with expression at $2 \%$. Data are presented as mean \pm S.D. from three independent experiments performed in triplicates. ${ }^{*} P \leqslant 0.05,{ }^{* *} P \leqslant 0.01$ such as ionomycin and A23187 (Figure 3d). Both, ionomycin and A23187 clearly induced the generation of a detectable $150 / 145 \mathrm{kDa}$ doublet only in HUVEC. These experiments excluded the possibility of insufficient protein separation and confirmed that no $145 \mathrm{kDa}$ fragment is generated in fusing BeWo cells.

According to literature, $\alpha$-fodrin is fragmented by the combined action of calpain and caspase $3 .^{25}$ To test whether or not these proteases were involved in $\alpha$-fodrin fragmentation in primary term trophoblasts and forskolin-treated BeWo cells, specific inhibitor peptides were applied to the cells. Calpeptin and calpain inhibitor III, both cell permeable calpain inhibitors, had no effect on $\alpha$-fodrin fragmentation, regardless of testing in forskolin-stimulated BeWo cells (Figure 4a) or primary trophoblasts (Figure 4b). To confirm that calpeptin and calpain inhibitor III were working correctly and specifically, BeWo and HUVEC cells were treated with ionomycin in the presence or absence of both calpain inhibitors. Although ionomycin did not induce $\alpha$-fodrin fragmentation into a $150 / 145 \mathrm{kDa}$ doublet in BeWo cells, it led to massive generation of both fragments in HUVEC (Figure 4c). In the presence of calpeptin or calpain inhibitor III, ionomycin-induced $\alpha$-fodrin fragmentation was almost completely blocked in HUVEC, confirming the efficiency of the applied inhibitors.

If inhibitors of caspase 8 or 3 (IETD or DEVD, respectively) were added to the culture medium, generation of the $120 \mathrm{kDa}$ fragment was diminished in forskolin-treated BeWo cells as well as primary term trophoblasts (Figure $4 \mathrm{a}$ and b). In both cell types, impaired generation of the $120 \mathrm{kDa}$ fragment was accompanied by an increase of the $150 \mathrm{kDa}$ cleavage product (Figure $4 \mathrm{a}$ and b). Besides caspases 8 and 3 inhibitors, also a caspase 9 inhibitor (LEHD) was able to inhibit the generation of the $120 \mathrm{kDa}$ fragment, but failed to inhibit the $150 \mathrm{kDa}$ fragment in forskolin-treated BeWo cells (Figure 4a) and
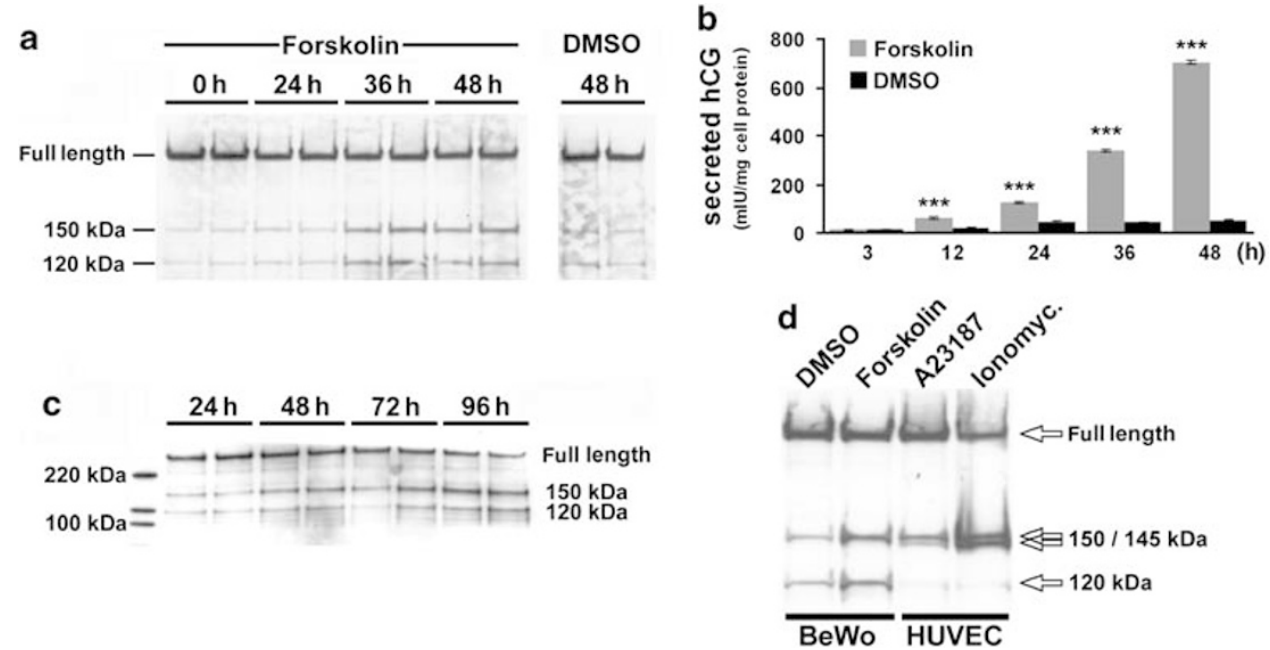

Figure 3 Fragmentation of $\alpha$-fodrin in BeWo cells, primary term trophoblasts and HUVEC. (a) Forskolin treatment $(20 \mu \mathrm{M})$ of BeWo cells led to a time-dependent fragmentation of $\alpha$-fodrin into 150 and $120 \mathrm{kDa}$ fragments. (b) Under these culture conditions, secretion of $\beta \mathrm{hCG}$ increased continuously in forskolin (20 $\mu \mathrm{M})$-treated BeWo cells (grey bars), whereas $\beta \mathrm{hCG}$ secretion remained constant in vehicle-treated cells (DMSO, $0.2 \%$, black bars); data are presented as mean \pm S.D. from three independent experiments performed in triplicates, ${ }^{\star \star \star} P \leqslant 0.001$. (c) Time-dependent fragmentation of $\alpha$-fodrin into 150 and $120 \mathrm{kDa}$ fragments also occurred in primary term trophoblasts. (d) No $145 \mathrm{kDa}$ fragment was generated in forskolin $(20 \mu \mathrm{M})$ and DMSO $(0.2 \%)$-treated BeWo cells after $48 \mathrm{~h}$. Treatment of HUVEC with calcium ionophores, A23187 (10 $\mu \mathrm{M}$, $1.5 \mathrm{~h})$ and ionomycin $(10 \mu \mathrm{M}, 2 \mathrm{~h})$-induced generation of a $150 / 145 \mathrm{kDa} \alpha$-fodrin doublet. Duplicate runs in (a) and (c) represent data of lysates from two independent cultures at indicated points of time. Western blots are representative for three independent experiments 

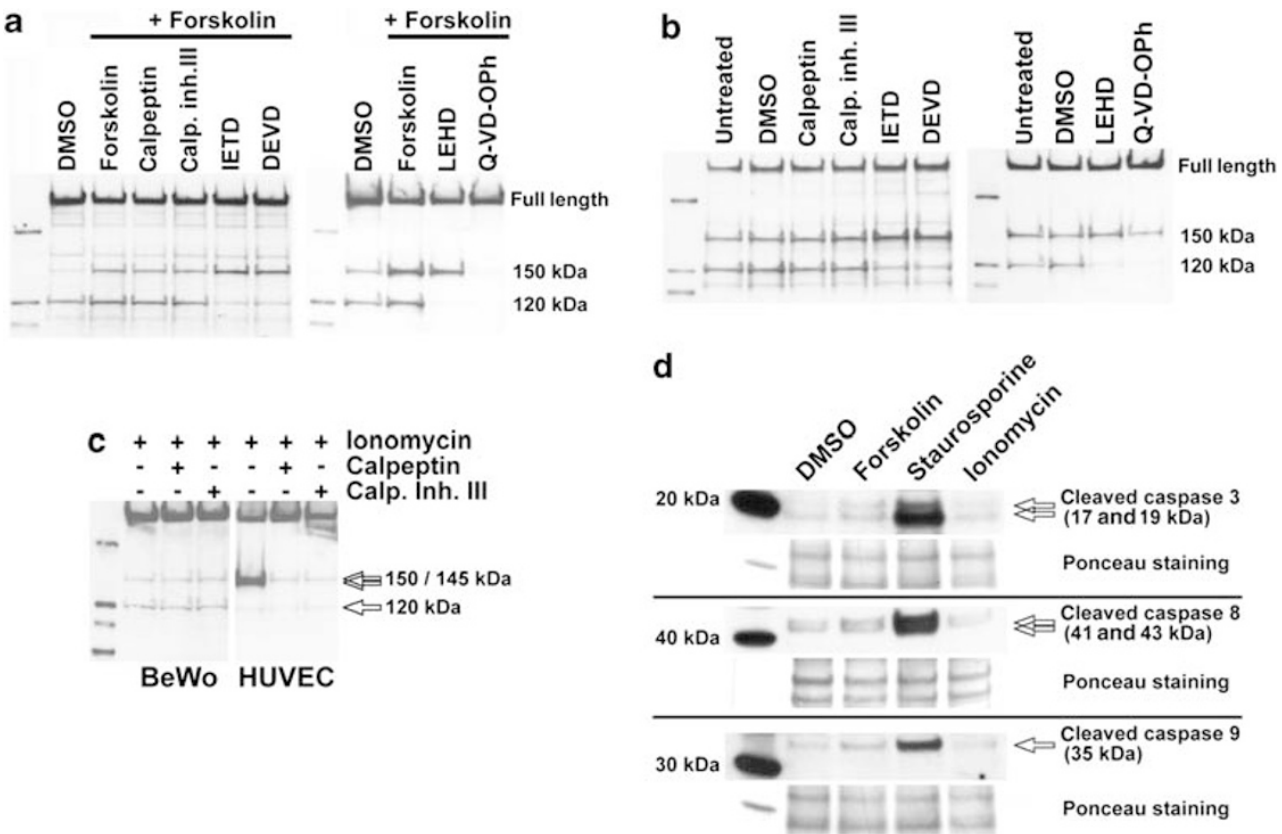

Figure 4 Effects of calpain inhibitors, general caspase inhibitor or individual caspase inhibitors 3,8 and 9 on $\alpha$-fodrin fragmentation in BeWo cells and primary term trophoblasts. (a) Inhibitors of caspases 3,8 and $9(20 \mu \mathrm{M}$, DEVD, IETD and LEHD, respectively) attenuated the generation of the $120 \mathrm{kDa} \alpha$-fodrin fragment in forskolin-treated $(20 \mu \mathrm{M})$ BeWo cells after $48 \mathrm{~h}$ cultivation. The inhibitors of calpain - calpeptin and calpain inhibitor III ( $20 \mu \mathrm{M}, 48 \mathrm{~h})$ - did not affect forskolin-induced fragmentation of $\alpha$-fodrin in BeWo cells. The general caspase inhibitor $(20 \mu \mathrm{M}, \mathrm{Q}-\mathrm{VD}-\mathrm{OPh})$ completely blocked $\alpha$-fodrin fragmentation in forskolin-treated $(20 \mu \mathrm{M}, 48 \mathrm{~h})$ BeWo cells. (b) Similar effects were observed in primary term trophoblasts after $48 \mathrm{~h}$ cultivation. (c) Efficiency of calpeptin and calpain inhibitor III was tested in ionomycin (10 $\mu \mathrm{M}, 2 \mathrm{~h})$-treated BeWo cells and HUVEC. Although $\alpha$-fodrin fragmentation was weak and not effected by calpain inhibitors in ionomycin-treated BeWo cells, ionomycin-induced pronounced generation of the $150 / 145 \mathrm{kDa} \alpha$-fodrin doublet in HUVEC, which was blocked in the presence of calpeptin and calpain inhibitor III. (d) Forskolin treatment $(20 \mu \mathrm{M}, 48 \mathrm{~h})$ led to a slight increase of cleavage products of caspases 3,8 and 9 (arrows) compared with vehicle control (DMSO, $0.2 \%)$. Staurosporine $(2 \mu \mathrm{M}, 2 \mathrm{~h})$, but not ionomycin (10 $\mu \mathrm{M}, 1.5 \mathrm{~h}$ ) strongly induced activation of caspases 3,8 and 9 in BeWo cells. Nitrocellulose membranes were stained with Ponceau S solution to verify equal protein loading and blotting efficiency. Western blots are representative for three independent experiments

primary term trophoblasts (Figure 4b). However, if the general caspase inhibitor Q-VD-OPh was present in the culture medium, $\alpha$-fodrin cleavage was almost entirely blocked in primary term trophoblasts (Figure 4b) and completely inhibited fragmentation in forskolin-treated BeWo cells (Figure 4a). Combined administration of calpain and caspase inhibitors did not alter the fragmentation patterns observed in experiments with individual application of caspase inhibitors (not shown).

However, caspase inhibitor experiments only indirectly showed caspase activation in fusing trophoblasts. Thus, western blots were performed to prove activation of caspases 3, 8 and 9 in forskolin-treated BeWo cells. Forskolin treatment slightly increased cleavage products of caspases 3, 8 and 9, compared with vehicle control after $48 \mathrm{~h}$ (Figure $4 \mathrm{~d}$ ), whereas $2 \mathrm{~h}$ incubation with staurosporine led to pronounced activation of caspases 3, 8 and 9. Ionomycin had only marginal effects on caspase activation in BeWo cells (Figure 4d).

BhCG secretion from trophoblasts was impaired by inhibitors of calpains and caspases. In BeWo cells, $\beta \mathrm{hCG}$ secretion increased during $48 \mathrm{~h}$ forskolin treatment 9.2-fold $(P<0.001)$, whereas calpeptin and calpain inhibitor III reduced forskolin-mediated $\beta \mathrm{hCG}$ secretion to $47.2 \%$ $( \pm 0.3 \%, \quad P<0.001)$ and $61.4 \% \quad( \pm 1.1 \%, \quad P<0.001)$, respectively (Figure $5 a$ ). Inhibitors of caspases 8 (IETD), 3
(DEVD) and 9 (LEHD) impaired $\beta$ hCG secretion from forskolin-treated BeWo cells to $67.1 \%( \pm 2.6 \%, P<0.001)$, $74.0 \%( \pm 1.6 \%, P<0.001)$ and $76.2 \%( \pm 1.3 \%, P<0.001)$, respectively, compared with controls. Besides individual caspase inhibitors, the general caspase inhibitor Q-VD-OPh reduced $\beta \mathrm{hCG}$ secretion in forskolin-treated BeWo cells to $66.5 \%( \pm 1.3 \%, P<0.001$; Figure $5 \mathrm{a})$.

Cultivation of primary term trophoblasts in the presence of calpeptin and calpain inhibitor III impaired secretion of $\beta \mathrm{hCG}$ to $27.6 \%( \pm 6.3 \%, P<0.001)$ and $41.0 \%( \pm 7.3 \%, P<0.001)$ after $48 \mathrm{~h}$ compared with conditions without inhibitors (Figure 5b). Inhibitors of caspases 8 (IETD), 3 (DEVD) and 9 (LEHD) led to a reduction in $\beta$ hCG secretion to $76.6 \%$ ( $\pm 6.6 \%, P=0.014), 78.8 \%( \pm 5.8 \%, P=0.018)$ and $83.0 \%$ ( $\pm 5.5 \%, P<0.05)$, respectively, compared with controls (Figure 5b). The general caspase inhibitor Q-VD-OPh decreased $\beta$ hCG secretion in primary term trophoblasts to $77.7 \%( \pm 1.2 \%, P<0.01)$.

Effect of calpain and caspase inhibitors on BeWo cell fusion. Forskolin stimulation of BeWo cells for $48 \mathrm{~h}$ enhanced syncytialization, as determined by the percentage of nuclei in syncytia, which increased from $5.8 \%( \pm 0.5 \%)$ to $36.0 \%( \pm 1.3 \%, P<0.001$ ) (Figure $5 \mathrm{c}$ ). Application of calpain inhibitors (calpeptin and calpain inhibitor III) or inhibitors of caspases 3 (DEVD) and 9 (LEHD) did not significantly affect 

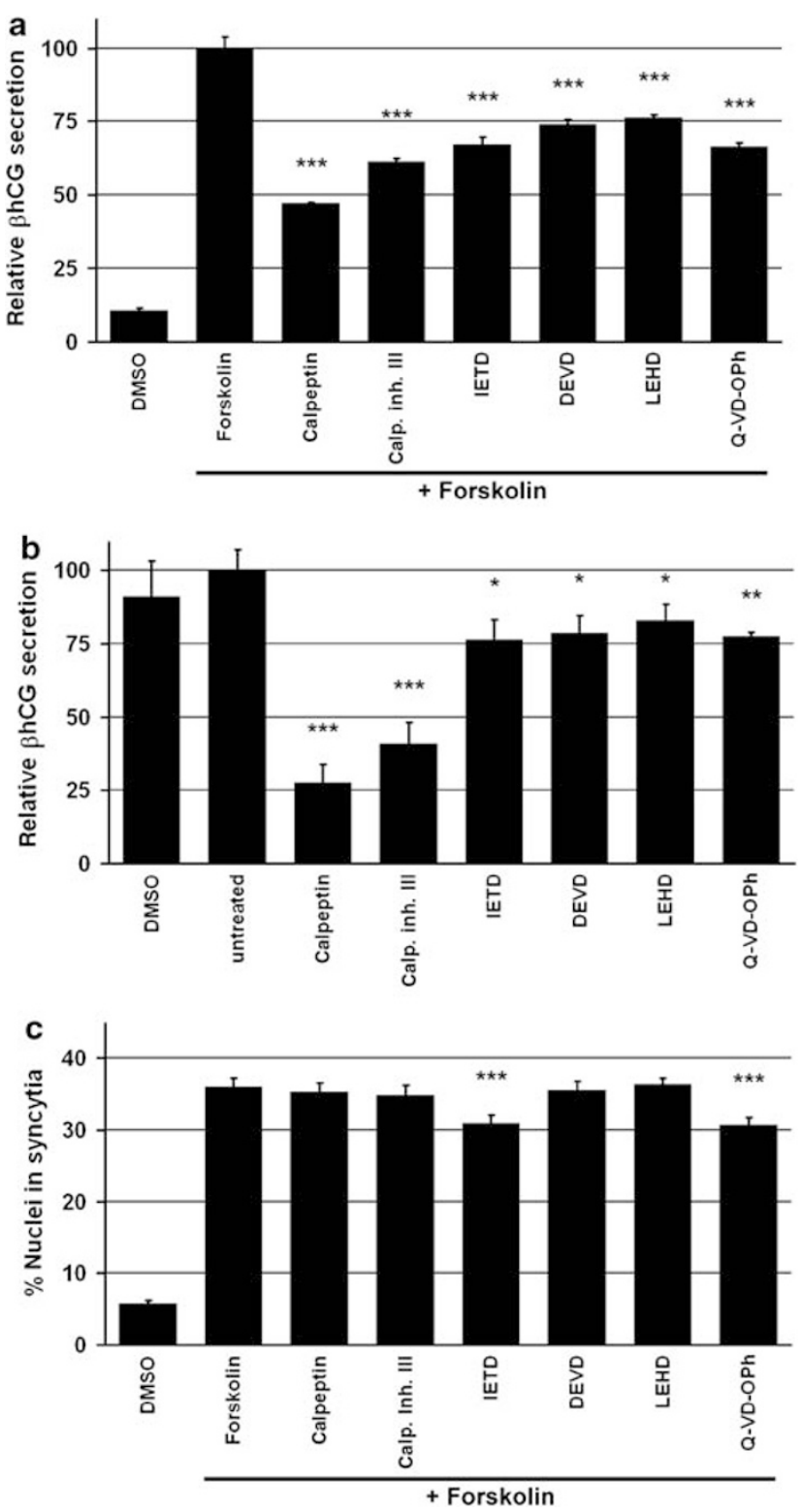

Figure 5 Effects of calpain and caspase inhibitors on $\beta \mathrm{hCG}$ secretion and syncytialization in BeWo cells and primary term trophoblasts. (a) Calpeptin and calpain inhibitor III $(20 \mu \mathrm{M})$, as well as individual caspase inhibitors of caspase 8 (IETD, $20 \mu \mathrm{M}$ ), caspase $3(\mathrm{DEVD}, 20 \mu \mathrm{M})$, caspase 9 (LEHD, $20 \mu \mathrm{M})$ and the general caspase inhibitor (Q-VD-OPh, $20 \mu \mathrm{M})$ decreased forskolin $(20 \mu \mathrm{M})$-induced $\beta \mathrm{hCG}$ secretion in BeWo cells after $48 \mathrm{~h}$. Secreted $\beta \mathrm{hCG}$ was normalized to total protein of treated cells. Secretion from BeWo cells treated with forskolin without inhibitor is given as $100 \%$. (b) Inhibitors showed similar effects on $\beta \mathrm{hCG}$ secretion in primary term trophoblasts after $48 \mathrm{~h}$. $\beta \mathrm{hCG}$ secretion from untreated primary term trophoblasts is given as $100 \%$. (c) Syncytialization of forskolin $(20 \mu \mathrm{M})$-treated BeWo cells was not affected by calpain inhibitors (calpeptin and calpain inhibitor III, $20 \mu \mathrm{M})$ and inhibitors of caspases $3($ DEVD, $20 \mu \mathrm{M})$ and 9 (LEHD, $20 \mu \mathrm{M})$ after $48 \mathrm{~h}$. Caspase 8 inhibitor (IETD, $20 \mu \mathrm{M}$ ) and the general caspase inhibitor Q-VD-OPh decreased syncytialization to 30.9 and $30.7 \%$, respectively, compared with BeWo cells treated with forskolin alone $(36.0 \%)$. Data are presented as mean \pm S.D. from three independent experiments performed in triplicates. ${ }^{\star} P \leqslant 0.05,{ }^{* *} P \leqslant 0.01,{ }^{* \star *} P \leqslant 0.001$

the fusion rate of forskolin-treated BeWo cells after $48 \mathrm{~h}$ $(35.3 \pm 1.2 \%, 34.9 \pm 1.3 \%, 35.5 \pm 1.2 \%$ and $36.3 \pm 1.0 \%$, respectively). However, if caspase 8 inhibitor (IETD) or the general caspase inhibitor (Q-VD-OPh) were added to BeWo cell cultures, fusion rates of forskolin-treated BeWo cells decreased to $30.9 \%( \pm 1.2 \%, P<0.001)$ and $30.7 \%( \pm 1.0 \%$, $P<0.001$ ), respectively (Figure 5c).

Active caspase 8 in villous trophoblasts of human placenta. Double staining of human first trimester placenta with anti- $\alpha$-fodrin and anti-cleaved-caspase- 8 antibodies showed active caspase 8 in few villous cytotrophoblasts (Figure 6a) as well as in restricted areas of the syncytiotrophoblast (Figure $6 \mathrm{~g}$ ). We have recently showed that one out of 422 villous cytotrophoblasts and one out of 759 nuclei within the syncytium had a perinuclear staining for active caspase $8 .^{26}$ Active caspase 8 was also observed in cytotrophoblasts, which detached from the basement membrane and obviously left the cell layer of mononucleated cytotrophoblasts towards the overlying syncytiotrophoblast (Figure 6d). In these cells, $\alpha$-fodrin, in particular after transition into the syncytium, appeared decomposed in vesicles as shown in the red channel (Figure $6 b$, e and $h$ ). Staining of cleaved caspase 8 was less intense in the syncytiotrophoblast compared with cytotrophoblasts positive for cleaved caspase 8 (Figure 6c, i).

\section{Discussion}

The data presented in this study provide evidence that villous cytotrophoblasts pursue two strategies to achieve remodelling of $\alpha$-fodrin during syncytialization. One route is downregulation of $\alpha$-fodrin mRNA, a mechanism likely to take place in the light of the loss of lateral cell borders and reduction of total membrane area in the syncytiotrophoblast. This finding is in line with down-regulation of other structural proteins such as $\mathrm{E}$-cadherin ${ }^{27}$ and desmoplakin, ${ }^{28}$ which are no longer needed after syncytialization.

The second route comprises proteolytic fragmentation of already existing $\alpha$-fodrin, which lines the inner membrane leaflet in villous cytotrophoblasts. Cleavage of $\alpha$-fodrin is implicated to affect cell shape and membrane morphology, as shown for platelet activation, which includes cell shape transformation from discs into irregular spheres. ${ }^{29}$ As degradation of the sub-membranous cytoskeleton network affects the membrane curvature, it is tempting to speculate that spatial fragmentation of the fodrin meshwork is required for fusion with adjacent cell membranes. This assumption is substantiated by the fact that the more curved a membrane is, the more fusogenic it becomes. ${ }^{30}$ For villous trophoblast, this means that a local disruption of the fodrin network, in combination with up-regulation of fusogenic membrane proteins, such as the endogenous viral envelope protein syncytin 1, would initiate membrane fusion with the overlying syncytiotrophoblast membrane.

Proteolytic breakdown of $\alpha$-fodrin into 150,145 and $120 \mathrm{kDa}$ fragments has been shown to be mediated alternatively by calpain and caspase 3 , depending on cell type and pathway of activation. ${ }^{13}$ However, in fusing trophoblasts $\alpha$-fodrin is only cleaved into 150 and $120 \mathrm{kDa}$ fragments, which may arise in a two-phase reaction, with an initial cleavage generating the $150 \mathrm{kDa}$ fragment and a second phase of producing a $120 \mathrm{kDa}$ fragment. ${ }^{31}$ Application of specific, cell permeable peptide 

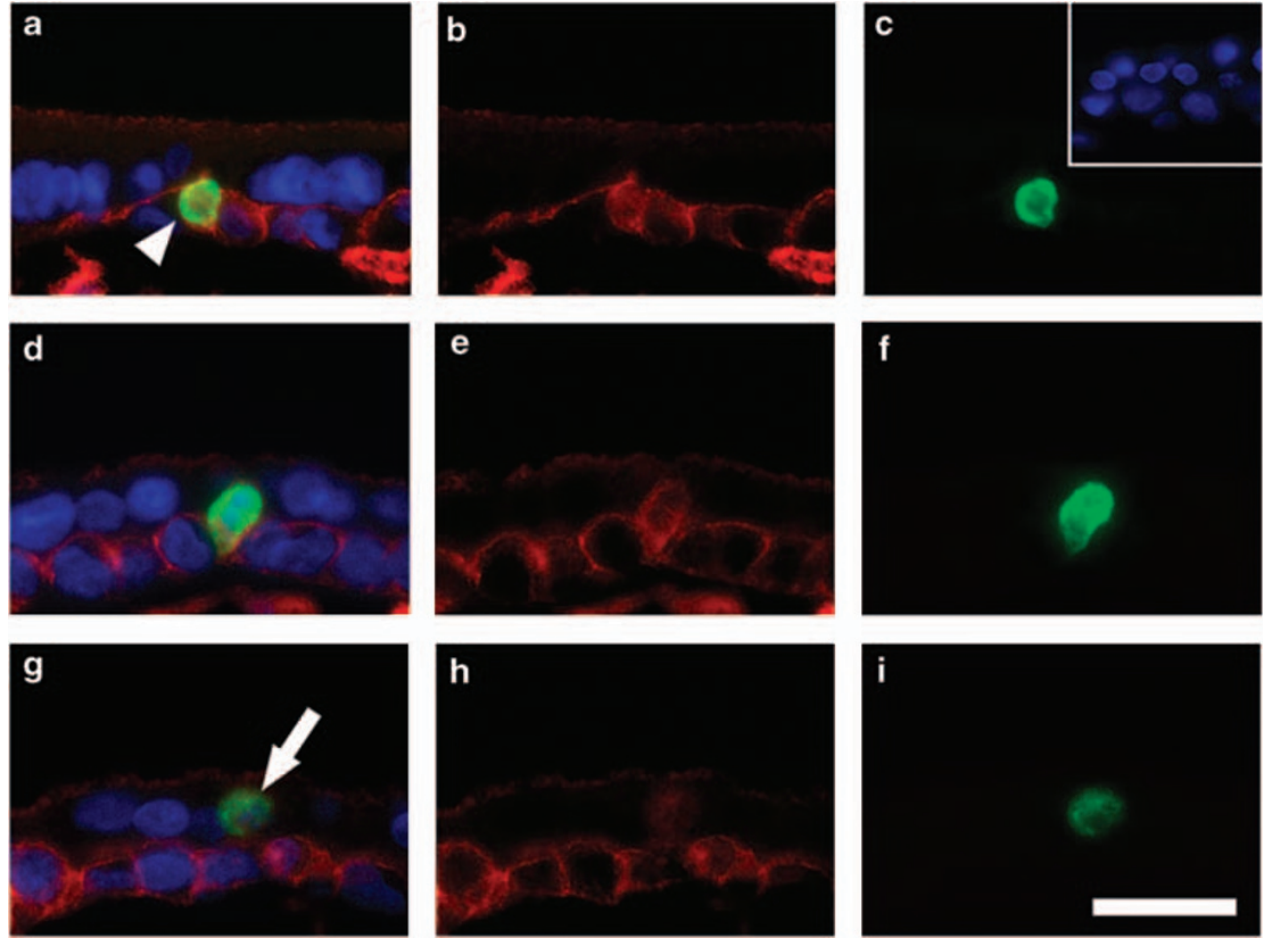

Figure 6 Double immunofluorescence staining of $\alpha$-fodrin and active caspase 8 in human first trimester placenta. First trimester placenta sections were stained for $\alpha$-fodrin (red: $\mathbf{b}, \mathbf{e}, \mathbf{h}$ ) and active caspase 8 (green: $\mathbf{c}, \mathbf{f}, \mathbf{i})$; overlay images are in $\mathbf{a}, \mathbf{d}, \mathbf{g}$. (a) Active caspase 8 was detected in few cytotrophoblasts (arrowhead) within the cytotrophoblast layer, (d) and also in cytotrophoblasts that seemed to detach from the basement membrane towards the syncytiotrophoblast. (g) In the syncytiotrophoblast (arrow), intensity of active caspase 8 staining was reduced compared with cytotrophoblasts positive for cleaved caspase 8 . (c, insert) Incubation with negative rabbit immunoglobulin fraction revealed no staining. Scale bar represents $20 \mu \mathrm{m}$

inhibitors of calpain and caspases provides strong evidence for an exclusive action of caspases, but not that of calpains in cleavage of $\alpha$-fodrin during trophoblast differentiation. Initial activation of pro-caspase 8 may lead to activation of caspases 9 and 3 , which subsequently results in $\alpha$-fodrin fragmentation.

Cleaved pro-caspase 8 can indeed be detected in a small subset of villous cytotrophoblasts as well as in cytotrophoblasts leaving the basement membrane towards the syncytiotrophoblast (Figure 6). Interestingly, staining of cleaved pro-caspase 8 co-localizes with $\alpha$-fodrin positive cytoplasmic vesicles, suggesting $\alpha$-fodrin degradation in those areas. The involvement of caspase 8 in trophoblast fusion is consistent with earlier findings, showing an inhibitory effect of caspase 8 antisense oligonucleotides or inhibitor peptides on fusion of cytotrophoblast with the syncytiotrophoblast in a human villous explant model. ${ }^{32}$

Here, we show a marginal effect of the caspase 8 inhibitor on BeWo cell fusion, whereas a much stronger effect of caspase 8 inhibitor was shown on trophoblast fusion in the placental villous explant model..$^{32} \mathrm{~A}$ comparison between two completely different in vitro models is always hard to draw. Interpretation of such data should always be carried out bearing in mind the cell type and microenvironment used for the study. Furthermore, it needs to be taken into account that BeWo cells are derived from a choriocarcinoma and thus most probably have alterations in their apoptosis programme. Hence, BeWo cells may have established other means than the use of caspase 8 to successfully fuse with other cells.
In any event, in both systems only inhibition of caspase 8 and not of calpains or caspase 3 or 9 led to a significant reduction in the rate of syncytial fusion.

Beside cleavage of $\alpha$-fodrin, active caspase 8 may also mediate externalization of phosphatidylserine to the outer leaflet, ${ }^{33,34}$ a process required in myotube formation, ${ }^{35}$ sperm-egg fusion $^{36}$ and trophoblast syncytialization. ${ }^{37}$ Caspase 8 acts upstream of caspase 3, but may additionally activate several other pathways during trophoblast fusion. This may explain why administration of caspase 3 inhibitor alone did not affect syncytialization of forskolintreated BeWo cells.

Calpains are not involved in $\alpha$-fodrin cleavage during trophoblast fusion, as two different inhibitors of calpains did not affect fragmentation. Secretion of $\beta \mathrm{hCG}$, however, is diminished in the presence of the applied calpain inhibitors. How calpains interfere with secretion of hCG, as observed after application of calpain inhibitors, remains to be elucidated.

As inhibitors of caspases 3,8 and 9 did not inhibit the generation of the $150 \mathrm{kDa}$ fragment of $\alpha$-fodrin during trophoblast fusion, the initial cleavage may be executed by other proteases. The general caspase inhibitor Q-VD-OPh completely blocked $\alpha$-fodrin cleavage in forskolin-challenged BeWo cells, which argues for the involvement of other caspases. Potential candidates are caspases 1, 2, 4, 6 and 7 , which are all able to generate the $150 \mathrm{kDa}$ fragment, presumably because of cleavage at a proteolytically 
hypersensitive site within $\alpha$-fodrin. ${ }^{24}$ This hypersensitive site is located near the junction repeat units 10-11 almost in the centre of $\alpha$-fodrin and is highly accessible to enzymatic cleavage. ${ }^{24,38}$ Recent in vitro experiments provide evidence that caspases 2 and 7 target the same cleavage site (at Asp-1185) as caspase $3,{ }^{39}$ suggesting that in trophoblast fusion the $150 \mathrm{kDa}$ fragment of $\alpha$-fodrin may be produced by one of these caspases. Administration of caspases 3 and 8 inhibitors only blocks the generation of the $120 \mathrm{kDa}$ fragment, leading to an accumulation of the $150 \mathrm{kDa}$ product. Similar effects were described earlier by Brown et al., ${ }^{14}$ who clearly showed that BD-fmk, a broad spectrum caspase inhibitor, was not able to inhibit the generation of the $150 \mathrm{kDa}$ fragment in a TGF- $\beta$-treated B-cell line. According to their study, generation of the $150 \mathrm{kDa}$ fragment arose by the action of different proteases and was rather not caspase specific. However, comparison of both studies is difficult as cells and types of stimuli were different.

Intercellular fusion of forskolin-treated BeWo cells is only marginally affected by the general caspase inhibitor $\mathrm{Q}-\mathrm{VD}-\mathrm{OPh}$, even though $\alpha$-fodrin fragmentation is completely blocked in the presence of the inhibitor. Hence, fragmentation of $\alpha$-fodrin may rather proceed right after the fusion process. This assumption is supported by immunofluorescence of human first trimester placenta, showing $\alpha$-fodrin decomposition in cytotrophoblasts, which have left the basal membrane towards the overlying syncytiotrophoblast. However, caspases, in particular caspase 8, may also activate pathways before fusion, as forskolin-induced syncytialization of BeWo cells is impaired not only by the general caspase inhibitor, but also by the individual inhibitor of caspase 8.

There is a growing body of evidence suggesting that caspases are not only involved in apoptosis, but also in other cellular processes such as cell-cycle regulation ${ }^{40}$ and differentiation. ${ }^{41}$ Increasing secretion of hCG from primary trophoblasts and forskolin-stimulated BeWo cells argues for differentiation into the syncytial state, rather than apoptosis to proceed. This resembles the in vivo situation, as the syncytiotrophoblast and not the villous cytotrophoblast expresses hCG. ${ }^{42}$ Caspase and calpain activities as well as cleavage of the sub-membranous fodrin cytoskeletal network seem to have their specific functions in trophoblast fusion.

\section{Materials and Methods}

Human placenta tissue samples. The study was approved by the ethical committee of the Medical University of Graz. Informed consent was obtained from the patients. Six first trimester placentas between weeks 6 and 12 of gestation were obtained from pregnancy terminations for psychosocial reasons. Three term placentas were obtained from uncomplicated pregnancies after delivery between weeks 38 and 40 . Tissue samples from first trimester and term placentas were fixed and paraffin embedded using the Hepes Glutamic Acid Buffer Mediated Organic Solvent Protection Effect (HOPE; Innovative Diagnostik Systeme, Hamburg, Germany) fixation technique, as described earlier. ${ }^{43}$

Culture of BeWo cells, primary term trophoblasts and HUVEC. BeWo cells were purchased from the European Collection of Cell Cultures and cultured according to the supplier's instructions. In brief, cells were cultured in a 1:1 mixture of DMEM (Gibco, Invitrogen, Paisley, UK) and Ham's F12K (Gibco), supplemented with $10 \%$ FCS, penicillin/streptomycin, amphotericin B, L-glutamine and non-essential amino acids. Cells between passage 10 and 20 were used for in vitro experiments. Syncytialization of BeWo cells was induced with forskolin. ${ }^{19}$
Cell culture medium was supplemented with forskolin (Sigma, St Louis, MO, USA) at a final concentration of $20 \mu \mathrm{M}(10 \mathrm{mM}$ stock in DMSO). Control cells were incubated with culture medium containing the same volume of DMSO $(0.2 \%)$.

Mononucleated term trophoblasts were isolated from chorionic villi by enzymatic digestion and Percoll density gradient centrifugation as described earlier. ${ }^{44}$ Primary term trophoblasts were cultured in DMEM (Gibco) supplemented with $10 \%$ FCS in a humidified atmosphere of $5 \% \mathrm{CO}_{2}$ at $37^{\circ} \mathrm{C}$.

HUVEC were purchased from PromoCell (Heidelberg, Germany) and cultured in EBM Endothelial Basal Medium (Lonza, Walkersville, MD, USA) including the supplement kit EGM-MV SingleQuots (Lonza).

Culture of BeWo cells at various oxygen concentrations. BeWo cells were plated in six-well dishes $\left(4 \times 10^{5}\right.$ cells/well) in DMEM/Ham's F12K $(2 \mathrm{ml} /$ well) and cultured in a hypoxic workstation (BioSpherix, Redfield, NY, USA) under $2,8,16$ and $20 \%$ oxygen for $48 \mathrm{~h}$. Cell culture supernatants, total protein and RNA were collected at indicated oxygen concentrations directly in the workstation. Experiments were performed in triplicates using three independent preparations.

Caspase and calpain inhibitor experiments. BeWo cells $\left(2 \times 10^{5}\right.$ cells/well) were plated in 12-well dishes in their appropriate culture medium 1 day before start of experiments. On the next day, cells were preincubated for $30 \mathrm{~min}$ with calpeptin (Z-Leu-NLe-CHO, Calbiochem, Darmstadt, Germany), calpain inhibitor III (Z-Val-Phe-CHO, Calbiochem), caspase 3 inhibitor peptide (Z-DEVD-FMK, BD PharMingen, Franklin Lakes, NJ, USA), caspase 8 inhibitor peptide (Z-IETD-FMK, BD PharMingen), caspase 9 inhibitor peptide (Z-LEHD-FMK, R\&D Systems, Minneapolis, MN, USA), general caspase inhibitor (Q-VD-OPh, R\&D Systems) or negative control peptide (Z-FA-FMK, BD PharMingen) at a concentration of $20 \mu \mathrm{M}$ each. Control cells were incubated with the same volume of DMSO, as all inhibitors were solubilized in this solvent. After preincubation, cells were incubated with medium containing the respective inhibitor together with either forskolin $(20 \mu \mathrm{M})$ or DMSO $(0.2 \%)$. At the same time, cells were also incubated only with forskolin or DMSO without inhibitors. After $48 \mathrm{~h}$ incubation, cells were lysed and lysates were subjected to immunoblot analyses.

Primary term trophoblasts $\left(2 \times 10^{5}\right.$ cells/well) were plated in 12-well dishes and cultivated in DMEM/10\% FCS with or without the respective inhibitors $(20 \mu \mathrm{M})$ for $48 \mathrm{~h}$. After incubation, cells were lysed and lysates were subjected to western blot analysis. Inhibitor experiments with BeWo cells and primary term trophoblasts were repeated three times using different cell preparations.

Treatment of BeWo cells and HUVEC with calcium ionophores and calpain inhibitors. BeWo cells $\left(4 \times 10^{5}\right.$ cells/well) and HUVEC $\left(2.8 \times 10^{5} \mathrm{cells} /\right.$ well) were plated in six-well dishes in their appropriate culture medium 1 day before start of experiments. Next day, cells were preincubated for 30 min with calpeptin $(20 \mu \mathrm{M})$, calpain inhibitor III $(20 \mu \mathrm{M})$ or vehicle control (DMSO, $0.2 \%)$. After preincubation, cells were treated with the calcium ionophores A23187 $(10 \mu \mathrm{M}, 2 \mathrm{~h}$; Sigma-Aldrich, St Louis, MO, USA) or ionomycin (10 $\mu \mathrm{M}, 1.5 \mathrm{~h}$; SigmaAldrich) in the presence or absence of the respective inhibitors. Experiments were repeated three times with different cell passages.

Measurement of secreted $\boldsymbol{\beta h C G}$. Culture medium of the cells was collected at indicated time points and centrifuged at 4000 r.p.m. for $10 \mathrm{~min}$. Supernatants were stored at $-20^{\circ} \mathrm{C}$ and subjected in groups to immunoassay analyses (Dimension Xpand; Dade Behring Inc., Deerfield, IL, USA). Values of secreted $\beta \mathrm{hCG}$ were normalized to total protein in cell lysates.

Immunofluorescence staining. BeWo cells $\left(8 \times 10^{4}\right)$ were plated in chamber-slides (Nunc, Rochester, NY, USA) 1 day before start of experiments. On the next day, medium was replaced by medium containing forskolin $(20 \mu \mathrm{M})$ or DMSO $(0.2 \%)$ and cells were cultivated for $48 \mathrm{~h}$. After incubation, cells were washed with PBS, dried and fixed for $10 \mathrm{~min}$ in acetone. Fixation was followed by rehydration with PBS and subsequent incubation with UV Block (LabVision, Fremont, CA, USA) for $7 \mathrm{~min}$. Primary antibody, anti- $\alpha$-fodrin (clone AA6, BioTrend, Köln, Germany), was diluted 1:100 in antibody diluent (DAKO, Carpintera, CA, USA) and applied to the slides for $30 \mathrm{~min}$. Slides were washed with PBS and incubated with secondary antibody, Alexa Fluor 555 goat anti-mouse (1:200; Invitrogen, Eugene, OR, USA) for $30 \mathrm{~min}$. Finally, slides were washed and nuclei were stained with DAPI (1:2000; Invitrogen) for $5 \mathrm{~min}$.

HOPE fixed, paraffin-embedded human first trimester placental tissues ${ }^{43}$ were cut in $5 \mu \mathrm{m}$ sections and mounted on Superfrost Plus slides (Menzel-Glaeser, Braunschweig, Germany). Sections were deparaffinized according to standard 
procedure. Slides were incubated with the primary antibody, anti- $\alpha$-fodrin $(1: 100)$, for $30 \mathrm{~min}$. Subsequently, slides were washed and incubated with Alexa Fluor 555 goat anti-mouse (1:200; Invitrogen) for $30 \mathrm{~min}$. Slides were washed and nuclei were stained with DAPI (1:2000; Invitrogen). For double staining of $\alpha$-fodrin and cleaved caspase 8 , slides were boiled in $10 \mathrm{mM}$ sodium citrate buffer $(\mathrm{pH} 6.0)$. Monoclonal mouse anti- $\alpha$-fodrin and monoclonal rabbit anti-cleaved-caspase- 8 antibody (clone 18C8, Cell Signaling, Beverly, MA, USA) were mixed and diluted in antibody diluent (both $1: 100$ ). Primary antibodies were incubated on the sections at $4^{\circ} \mathrm{C}$ over night. Slides were washed and incubated with a mixture of Alexa Fluor 555 goat anti-mouse and Alexa Fluor 488 goat anti-rabbit antibodies (both 1:200, Invitrogen) for $30 \mathrm{~min}$ at room temperature. For negative controls, rabbit immunoglobulin fraction (DAKO) or negative control mouse IgG1 (DAKO) were diluted in antibody diluent $(1 \mu \mathrm{g} / \mathrm{ml})$ and incubated on slides as described above. Incubation with negative control immunoglobulins revealed no staining. After staining procedure, cells as well as tissue sections were mounted with ProLong Gold antifade reagent (Invitrogen). Fluorescence microscopy was performed using an Axiophot and an AxioCam HRc (Zeiss, Oberkochen, Germany).

Assessment of syncytialization. BeWo cells were treated as described in the immunofluorescence section and stained according to the protocol. Instead of the anti- $\alpha$-fodrin antibody, a monoclonal anti-E-cadherin antibody (1:15 diluted; Acris $\mathrm{GmbH}$, Hiddenhausen, Germany) was applied to visualize cell-cell contacts. For unbiased quanitification of BeWo cell syncytialization, a microscope (Leica, Wetzlar, Germany; DM6000B), equipped with a motorized stage, a digital camera (Olympus, Hamburg, Germany; DP72) and the newCAST stereology software (Visiopharm) was used. The system systematically randomly selected and microphotographed 20 positions per chamber ( $\times 20$ objective). Counting frames, which covered $80 \%$ of every single image, were applied to the images and nuclei in syncytia were counted and related to the total number of nuclei in the selected areas. All fusion experiments were conducted in triplicate and repeated thrice with different BeWo cell passages.

Immunoblotting. Cells were washed with PBS and lysed in lysis buffer ( $10 \mathrm{mM}$ Tris $\mathrm{pH} 7,1 \% \mathrm{SDS}, 1 \mathrm{mM}$ sodium-orthovanadate and a protease inhibitor cocktail). Protein concentration was determined by the Lowry technique and for $\alpha$-fodrin immunodetection, $30 \mu \mathrm{g}$ total protein were applied to precast 3-8\% Tris-acetate gels (NuPAGE, Novex; Invitrogen). After electrophoresis, proteins were semi-dry blotted on a $0.45 \mu \mathrm{m}$ nitrocellulose membrane (Hybond, Amersham Biosciences, Little Chalfont, UK). Blotting efficiency was determined by staining the nylon membranes with Ponceau S solution (Sigma-Aldrich). Immunodetection was conducted with a chemiluminescent immunodetection kit (Western Breeze; Invitrogen) according to the manufacturers' instructions. Monoclonal anti- $\alpha$-fodrin (clone AA6, BioTrend, Köln, Germany) was diluted in blocking solution $1: 2000$ and applied to the membrane for $1 \mathrm{~h}$ at RT.

For detection of cleaved caspases, $30 \mu \mathrm{g}$ total protein of forskolin $(20 \mu \mathrm{M}, 48 \mathrm{~h})$ or DMSO $(0.2 \%, 48 \mathrm{~h})$-treated BeWo cells were separated on $4-12 \%$ Bis-Tris gels (NuPAGE, Invitrogen). For controls, lysates were used from BeWo cells treated with staurosporine ( $2 \mu \mathrm{M}, 2 \mathrm{~h}$; Alexis Biochemicals, Lausen, Switzerland) or ionomycin $(10 \mu \mathrm{M}, 1.5 \mathrm{~h})$. Blotting and chemiluminescent immunodetection were performed as described above. Primary antibodies, monoclonal anti-cleaved caspase 3 (clone $5 \mathrm{~A} 1 \mathrm{E})$, monoclonal anti-cleaved caspase 8 (clone 18C8) and polyclonal anticleaved caspase 9 (all Cell Signaling), were diluted 1: 1000 and incubated with the membrane over night at $4^{\circ} \mathrm{C}$.

Microarray analyses. Applied Biosystems Human Genome Survey Arrays were used to determine the transcriptional profiles of BeWo cells treated with forskolin $(20 \mu \mathrm{M}, 48 \mathrm{~h})$ or DMSO $(0.2 \%, 48 \mathrm{~h})$. DIG-labelled cDNA probes were generated by reverse transcription of $20 \mu \mathrm{g}$ total RNA using the Chemiluminescent RT-Labeling kit (Applied Biosystems, Foster City, CA, USA) as described by the manufacturer's protocols. Array hybridization, chemiluminescence detection, image acquisition and analysis were performed using Applied Biosystems Chemiluminescence Detection Kit and Applied Biosystems 1700 Chemiluminescence Microarray Analyzer following the manufacturers' instructions.

Each microarray was first pre-hybridized at $55^{\circ} \mathrm{C}$ for $1 \mathrm{~h}$ in hybridization buffer with blocking reagent. Oligo-dT-primed, DIG-labelled cDNA targets were fragmented, mixed with internal control target and then hybridized to the equilibrated microarrays in a volume of $1.5 \mathrm{ml}$ at $55^{\circ} \mathrm{C}$ for $16 \mathrm{~h}$. After hybridization, the arrays were washed with hybridization wash buffer and chemiluminescence rinse buffer. Enhanced chemiluminescent signals were generated by incubating arrays with alkaline phosphatase-conjugated anti-digoxigenin antibody followed by incubation with Chemiluminescence Enhancing Solution and a final addition of Chemiluminescence Substrate. Four images were collected for each microarray using the ABI 1700 Chemiluminescent Microarray Analyzer. Images were auto-gridded and the chemiluminescence signals were quantified, corrected for background and spot and spatially normalized.

Real-time RT-PCR analyses. Total RNA was isolated with the Tri Reagent (Molecular Research Center, Cintinnati, OH, USA) according to the manufacturers' instructions. The quality of BeWo total RNA (RIN 9.0-9.6) was assessed with a bioanalyzer (2100 Bioanalyzer, Agilent Technologies, Santa Clara, CA, USA). Reverse transcription of total RNA was performed with High-Capacity cDNA Reverse Transcription Kit (Applied Biosystems, Foster City, CA, USA) according to manufacturer's manual. In brief, $2 \mu \mathrm{g}$ total RNA of each sample was mixed with the kit components in a total reaction volume of $20 \mu \mathrm{l}$ and incubated for $10 \mathrm{~min}$ at $25^{\circ} \mathrm{C}$, $120 \mathrm{~min}$ at $37^{\circ} \mathrm{C}$ and $5 \mathrm{~s}$ at $85^{\circ} \mathrm{C}$ in a thermocycler.

Real-time PCR was performed using the QuantiFast SYBR Green PCR Kit (Qiagen, Hilden, Germany) and QuantiTect Primer Assays (Qiagen) for alphafodrin (Hs_SPTAN1_1_SG QuantiTect Primer Assay) and ribosomal protein P0 (RPLP0, Hs_RPLP0_1_SG QuantiTect Primer Assay), used as internal reference. A total of $8.8 \mu \mathrm{l}$ of $\mathrm{CDNA}(10 \mathrm{ng} / \mu \mathrm{l})$ were mixed with $2.2 \mu \mathrm{l}$ primers and $11 \mu \mathrm{l}$ SYBR green mastermix. Expression levels were analysed in triplicates in a volume of $6 \mu \mathrm{l}$ per well in a 384-well plate (Roche, Mannheim, Germany) in a LightCycler 480 (Roche). PCR conditions contained an initial 5 min denaturing step at $95^{\circ} \mathrm{C}$ and a subsequent two-step cycling including $10 \mathrm{~s}$ at $95^{\circ} \mathrm{C}$ and $30 \mathrm{~s}$ at $60^{\circ} \mathrm{C}$ for 40 cycles. $\mathrm{Ct}$ values were automatically generated by the LightCycler 480 Software (Roche) and relative quantification of gene expression was calculated by standard $\Delta \Delta \mathrm{Ct}$ method using the expression of RPLPO as reference.

Statistical analysis. Data are presented as mean \pm S.D. and were tested using Student's $t$-test for differences between groups using SigmaPlot 11.0 and MS Excel 2003. Significances were accepted at a level $P<0.05$.

Acknowledgements. This work was supported by grants from the EU (Grant \# 037244, project title Pregenesys) and the Franz-Lanyar-Foundation (Projects \# 321 and \# 331).

1. Richart R. Studies of placental morphogenesis. I. Radioautographic studies of human placenta utilizing tritiated thymidine. Proc Soc Exp Biol Med 1961; 106: 829-831.

2. Gauster M, Moser G, Orendi K, Huppertz B. Factors involved in regulating trophoblast fusion: potential role in the development of preeclampsia. Placenta 2009; 30 (Suppl A): S49-S54.

3. Hamasaki K, Ueda H, Okamura Y, Fujimoto S. Double immunoelectron microscopic labelings of human chorionic gonadotropin and human placental lactogen in human chorionic villi. J UOEH 1988; 10: 171-177.

4. Señarís R, Garcia-Caballero T, Casabiell X, Gallego R, Castro R, Considine RV et al. Synthesis of leptin in human placenta. Endocrinology 1997; 138: 4501-4504.

5. Inkster SE, Brodie AM. Immunocytochemical studies of aromatase in early and full-term human placental tissues: comparison with biochemical assays. Biol Reprod 1989; 41: 889-898.

6. Kitawaki J, Inoue S, Tamura T, Yamamoto T, Noguchi T, Osawa Y et al. Increasing aromatase cytochrome P-450 level in human placenta during pregnancy: studied by immunohistochemistry and enzyme-linked immunosorbent assay. Endocrinology 1992; 130: 2751-2757.

7. Adler RR, Ng AK, Rote NS. Monoclonal antiphosphatidylserine antibody inhibits intercellular fusion of the choriocarcinoma line, JAR. Biol Reprod 1995; 53: 905-910.

8. Frendo JL, Cronier L, Bertin G, Guibourdenche J, Vidaud M, Evain-Brion D et al. Involvement of connexin 43 in human trophoblast cell fusion and differentiation. J Cell Sci 2003; 116 (Pt 16): 3413-3421.

9. Frendo JL, Olivier D, Cheynet V, Blond JL, Bouton O, Vidaud M et al. Direct involvement of HERV-W Env glycoprotein in human trophoblast cell fusion and differentiation. Mol Cell Biol 2003; 23: 3566-3574.

10. Kudo Y, Boyd CA. RNA interference-induced reduction in CD98 expression suppresses cell fusion during syncytialization of human placental BeWo cells. FEBS Lett 2004; 577: 473-477.

11. Chen A, Leikina E, Melikov K, Podbilewicz B, Kozlov MM, Chernomordik LV. Fusion-pore expansion during syncytium formation is restricted by an actin network. J Cell Sci 2008; 121 (Pt 21): 3619-3628.

12. Martin SJ, O'Brien GA, Nishioka WK, McGahon AJ, Mahboubi A, Saido TC et al. Proteolysis of fodrin (non-erythroid spectrin) during apoptosis. J Biol Chem 1995; 270: 6425-6428.

13. Simonovic M, Zhang Z, Cianci CD, Steitz TA, Morrow JS. Structure of the calmodulin alphall-spectrin complex provides insight into the regulation of cell plasticity. J Biol Chem 2006; 281: 34333-34340. 
14. Brown TL, Patil S, Cianci CD, Morrow JS, Howe PH. Transforming growth factor beta induces caspase 3-independent cleavage of alphall-spectrin (alpha-fodrin) coincident with apoptosis. J Biol Chem 1999; 274: 23256-23262.

15. Vaisid T, Kosower NS, Barnoy S. Caspase-1 activity is required for neuronal differentiation of PC12 cells: cross-talk between the caspase and calpain systems. Biochim Biophys Acta 2005; 1743: 223-230.

16. Lee A, Fischer RS, Fowler VM. Stabilization and remodeling of the membrane skeleton during lens fiber cell differentiation and maturation. Dev Dyn 2000; 217 : 257-270.

17. Lee A, Morrow JS, Fowler VM. Caspase remodeling of the spectrin membrane skeleton during lens development and aging. J Biol Chem 2001; 276: 20735-20742.

18. Barnoy S, Maki M, Kosower NS. Overexpression of calpastatin inhibits L8 myoblast fusion. Biochem Biophys Res Commun 2005; 332: 697-701.

19. Wice B, Menton D, Geuze H, Schwartz AL. Modulators of cyclic AMP metabolism induce syncytiotrophoblast formation in vitro. Exp Cell Res 1990; 186: 306-316.

20. Alsat E, Wyplosz P, Malassiné A, Guibourdenche J, Porquet D, Nessmann C et al. Hypoxia impairs cell fusion and differentiation process in human cytotrophoblast, in vitro. J Cell Physiol 1996; 168: 346-353.

21. Hu R, Jin H, Zhou S, Yang P, Li X. Proteomic analysis of hypoxia-induced responses in the syncytialization of human placental cell line BeWo. Placenta 2007; 28: 399-407.

22. Kudo Y, Boyd CA, Sargent IL, Redman CW. Hypoxia alters expression and function of syncytin and its receptor during trophoblast cell fusion of human placental BeWo cells: implications for impaired trophoblast syncytialisation in pre-eclampsia. Biochim Biophys Acta 2003; 1638: 63-71.

23. Sibley CP, Pardi G, Cetin I, Todros T, Piccoli E, Kaufmann P et al. Pathogenesis of intrauterine growth restriction (IUGR)-conclusions derived from a European Union Biomed 2 Concerted Action project 'Importance of Oxygen Supply in Intrauterine Growth Restricted Pregnancies'-a workshop report. Placenta 2002; 23 (Suppl A): S75-S79.

24. Wang KK, Posmantur R, Nath R, McGinnis K, Whitton M, Talanian RV et al. Simultaneous degradation of alphall- and betall-spectrin by caspase 3 (CPP32) in apoptotic cells. J Biol Chem 1998; 273: 22490-22497.

25. Wang KK. Calpain and caspase: can you tell the difference? Trends Neurosci 2000; 23 20-26.

26. Gauster M, Siwetz M, Huppertz B. Fusion of villous trophoblast can be visualized by localizing active caspase 8. Placenta 2009; 30: 547-550.

27. Coutifaris C, Kao LC, Sehdev HM, Chin U, Babalola GO, Blaschuk OW et al. E-cadherin expression during the differentiation of human trophoblasts. Development 1991; 113: 767-777.

28. Douglas GC, King BF. Differentiation of human trophoblast cells in vitro as revealed by immunocytochemical staining of desmoplakin and nuclei. J Cell Sci 1990; 96 (Pt 1): 131-141.
29. Fox JE, Reynolds CC, Morrow JS, Phillips DR. Spectrin is associated with membranebound actin filaments in platelets and is hydrolyzed by the $\mathrm{Ca} 2+$-dependent protease during platelet activation. Blood 1987; 69: 537-545.

30. Martens S, McMahon HT. Mechanisms of membrane fusion: disparate players and common principles. Nat Rev Mol Cell Biol 2008; 9: 543-556.

31. Greidinger EL, Miller DK, Yamin TT, Casciola-Rosen L, Rosen A. Sequential activation of three distinct ICE-like activities in Fas-ligated Jurkat cells. FEBS Lett 1996; 390: 299-303.

32. Black S, Kadyrov M, Kaufmann P, Ugele B, Emans N, Huppertz B. Syncytial fusion of human trophoblast depends on caspase 8. Cell Death Differ 2004; 11: 90-98.

33. Mandal D, Mazumder A, Das P, Kundu M, Basu J. Fas-, caspase 8-, and caspase 3-dependent signaling regulates the activity of the aminophospholipid translocase and phosphatidylserine externalization in human erythrocytes. J Biol Chem 2005; 280: 39460-39467.

34. Ohtani T, Hatori M, Ito H, Takizawa K, Kamijo R, Nagumo M. Involvement of caspases in 5-FU induced apoptosis in an oral cancer cell line. Anticancer Res 2000; 20 (5A): 3117-3121

35. Sessions A, Horwitz AF. Differentiation-related differences in the plasma membrane phospholipid asymmetry of myogenic and fibrogenic cells. Biochim Biophys Acta 1983; 728: 103-111.

36. Gadella BM, Harrison RA. The capacitating agent bicarbonate induces protein kinase A-dependent changes in phospholipid transbilayer behavior in the sperm plasma membrane. Development 2000; 127: 2407-2420.

37. Huppertz B, Frank HG, Kingdom JC, Reister F, Kaufmann P. Villous cytotrophoblast regulation of the syncytial apoptotic cascade in the human placenta. Histochem Cell Biol 1998; 110: 495-508.

38. Harris AS, Morrow JS. Proteolytic processing of human brain alpha spectrin (fodrin): identification of a hypersensitive site. J Neurosci 1988; 8: 2640-2651.

39. Rotter B, Kroviarski Y, Nicolas G, Dhermy D, Lecomte MC. Alphall-spectrin is an in vitro target for caspase-2, and its cleavage is regulated by calmodulin binding. Biochem J 2004; 378 (Pt 1): 161-168.

40. Los M, Stroh C, Janicke RU, Engels IH, Schulze-Osthoff K. Caspases: more than just killers? Trends Immunol 2001; 22: 31-34.

41. Lamkanfi M, Festjens N, Declercq W, Vanden Berghe T, Vandenabeele P. Caspases in cell survival, proliferation and differentiation. Cell Death Differ 2007; 14: 44-55.

42. Billingsley SA, Wooding FB. An immunogold, cryoultrastructural study of sites of synthesis and storage of chorionic gonadotropin and placental lactogen in human syncytiotrophoblast. Cell Tissue Res 1990; 261: 375-382.

43. Blaschitz A, Gauster M, Dohr G. Application of cryo-compatible antibodies to human placenta paraffin sections. Histochem Cell Biol 2008; 130: 595-599.

44. Cervar M, Blaschitz A, Dohr G, Desoye G. Paracrine regulation of distinct trophoblast functions in vitro by placental macrophages. Cell Tissue Res 1999; 295: 297-305. 